\title{
GREThA
}

Groupe de Recherche en

Économie Théorique et Appliquée

\section{Patents as a Measure for Eco-Innovation}

\section{Vanessa Oltra}

Université de Bordeaux

GREThA UMR CNRS 5113

\section{René Kemp}

NU-MERIT \& ICIS, University of Maastricht, The Netherlands DRIFT, Erasmus University Rotterdam, The Netherlands

\section{Frans $P$. de Vries}

Stirling Management School, University of Stirling, UK

Cahiers du GREThA

$n^{\circ}$ 2009-05 


\title{
Les brevets comme mesure des innovations environnementales
}

\begin{abstract}
Résumé
Cet article est consacré à l'utilisation des données de brevets pour mesurer et évaluer les innovations environnementales. Nous montrons que, malgré des difficultés méthodologiques, les données de brevets peuvent être utilisées afin d'évaluer les activités d'innovation dans le domaine des écotechnologies, qu'ils s'agissent de technologies de contrôle ou de traitement de la pollution, de procédés ou de produits dits "propres". La principale difficulté méthodologique est liée à l'identification des "éco-brevets" qui nécessite une méthodologie de recherche combinant plusieurs critères (codes IPC, motsclés). A partir d'une revue de la littérature, nous montrons que les brevets peuvent être utilisés pour évaluer cinq attributs des activités d'innovation environnementale : les activités d'invention dans certains domaines technologiques spécifiques, la diffusion internationale de certaines technologies environnementales, les compétences technologiques et les champs de recherche des organisations, les sources des écoinnovations, et enfin, les spillovers et les flux de connaissances.
\end{abstract}

Mots-clés : Innovations environnementales, éco-technologies, brevets

\section{Patents as a Measure for Eco-Innovation}

\begin{abstract}
This paper examines the usefulness of patent analysis for measuring eco-innovation. The overall conclusion is that patents are a useful means for measuring environmentally motivated innovations, such as pollution control technologies and green energy technologies, and for general purpose technologies with environmental benefits. For these types of innovations it is acceptable to use patent analysis, provided they are carefully screened. Patent analysis may be used for measuring five attributes of ecoinnovation: (1) eco-inventive activities in specific technology fields, (2) international technological diffusion, (3) research and technical capabilities of companies, (4) institutional knowledge sources of eco-innovation, and (5) technological spillovers and knowledge flows. Up until now it is mainly used for measuring eco-inventive activity.
\end{abstract}

Keywords: Eco-innovation, patents

JEL : Q55, 034, C81

Reference to this paper:Vanessa OLTRA, René KEMP, F, Frans. De Vries, "Patents as a Measure for Eco-Innovation", Working Papers of GREThA, n² 2009-05 http://ideas.repec.org/p/grt/wpegrt/2009-05.html. 


\section{Introduction ${ }^{1}$}

The measurement of technological innovation has long preoccupied economists. Research and development (R\&D) and patent data have emerged as important indicators of the innovativeness of an economy or sectors. Measuring technological change presents a common and well-known problem for innovation output research. In practice, four different types of measures are generally used to quantify technological change. The first one represent input measures such as R\&D expenditures, R\&D personnel, the number of researchers, and innovation expenditures. Second, there are direct measures of innovative output like the number of innovations, descriptions of individual innovations or data on sales of new products. The third class comprises indirect measures derived from aggregate data such as changes in resource efficiency or productivity using decomposition analysis. The fourth class represent intermediate output measures, including the number of patents and the amount and type of scientific publications.

Given the enormous growth in the number of patent applications worldwide, and the increasing use of patent data in economic analyses, the aim of this paper is to give an account of the use of patent data as a measure for innovation in the environmental domain, viz. ecoinnovation. Measuring eco-innovation is important for various reasons: (i) for evaluating progress within various categories of eco-innovation, (ii) for identifying shifts in ecoinnovation approaches (for example the shift from curative to preventive measures), (iii) for assessing which nations are leading and which ones are lagging in specific fields, and (iv) for analyzing the various drivers of eco-innovation and projecting the associated economic and environmental consequences. The be able to give an answer on how eco-innovation can be measured through the use of patents, let us first put patents into a slightly broader perspective.

A patent is an exclusive right to exploit (make, use, sell, or import) an invention over a limited period of time (usually 20 years from filing) within the country where the application is made. Patents are granted for inventions which are novel, inventive (non-obvious) and have an industrial application (useful) (OECD, 2004, p.8). Patents have several advantages over R\&D expenditures: (i) they explicitly give an indication of inventive output, (ii) they can be disaggregated by technology group, and (iii) they combine detail and coverage of technologies (Lanjouw et al., 1998). Moreover, because patents are granted on the basis of novelty and utility, they are based on an objective and slowly changing standard (Griliches, 1990). Furthermore, patents are an intermediate output measure for innovation, to be distinguished from input measures (such as R\&D expenditures), direct measure of innovative output and indirect measures derived from aggregate data.

This article is based on our work for the Measuring Eco-Innovation (MEI) project funded by DG research of the European Commission. http://www.merit.unu.edu/MEI/ 
In the following section we will start with a short discussion of these measures and will confine the concept of eco-innovation. In section 3, we discuss the use of patents as an indicator of eco-innovation. Section 4 examines some methodological issues linked to ecopatents. Section 5 contains our conclusions.

\section{Defining eco-innovation and how to measure it}

Eco-innovation is a fairly recent concept. One of the first appearances of the concept of eco-innovation in the literature is in the book by Fussler and James (1996). In a subsequent article, eco-innovation is defined as "new products and processes which provide customer and business value but significantly decrease environmental impacts” (James, 1997).

Denmark's government defines eco-innovation as innovation leading to an ecoefficient technology in the white paper "Promoting Eco-efficient Technology - The Road to a Better Environment”. Eco-efficient technology here refers to all technologies which directly or indirectly improve the environment. It includes technologies to limit pollution, more environmentally friendly products and production processes, more effective resource management, and technological systems to reduce environmental impacts. The SYSTEMATIC panel on eco-innovation defines eco-innovation as "the creation of novel and competitively priced goods, processes, systems, services, and procedures designed to satisfy human needs and provide a better quality of life for everyone with a life-cycle minimal use of natural resources (materials including energy and surface area) per unit output, and a minimal release of toxic substances” (Technopolis, 2008, p.2).

Eco-innovation is often used as shorthand for environmental innovation (Rennings, 2000; Europe Innova). There exist various definitions of environmental innovation. One such definition says that environmental innovations comprise new and modified processes, equipment, products, techniques and management systems that avoid or reduce harmful environmental impacts (Kemp and Arundel, 1998; Kemp et al., 2001; Rennings and Zwick, 2003). There is no reference to motivation in this definition. The distinguishing feature is the environmental gain (compared to relevant alternatives), which is also the defining feature of the concept of environmental technologies that is used in the European Commission's Environmental Technologies Action Plan (ETAP). According to ETAP, environmental technologies encompass technologies and processes to manage pollution (e.g. air pollution control, waste management), less polluting and less resource-intensive products and services and ways to manage resources more efficiently (e.g. water supply, energy-saving technologies). Environmental technologies are technologies whose use is less environmental harmful than relevant alternatives.

As with technologies in general, innovation is also embedded in environmental technologies. The adoption of technology also counts as innovation according to the Oslo Manual for measuring innovation (OECD, 2005). What this shows is that innovation is a relative concept, not an absolute concept (Arundel and Kemp, 2009). When measuring ecoinnovation one should thus make clear whether one is measuring the creation of product innovations or the implementation of products, technologies, services and practices. Another distinction is whether the innovation is an incremental improvement of something that exists or something entirely new (Arundel and Kemp, 2009).

Eco-innovation may be defined on the basis of motivation and on the basis of performance. Most studies of eco-innovation have focussed on environmentally motivated innovation. We propose to base the definition of an eco-innovation on the associated 
environmental benefit(s). That is, the primary issue is whether there is an environmental benefit, rather than just an environmental aim. The environmental performance should be assessed on a life-cycle basis and not just at one point in the value chain.

More formally, we propose to make use of the definition for eco-innovation as developed in the MEI project for the European Commission:

Eco-innovation is the production, assimilation or exploitation of a product, production process, service or management or business method that is novel to the organisation (developing or adopting it) and which results, throughout its life cycle, in a reduction of environmental risk, pollution and other negative impacts of resources use (including energy use) compared to relevant alternatives.

The definition follows the convention in innovation measurement (e.g. the Oslo Manual; OECD, 2005) that the innovation does not have to be new to the world; it only has to be new to the company developing or adopting it. It is important to stress that this definition provides a weak conceptual demarcation. Almost all firms who innovate will be ecoinnovators, which may strike some people as too broad a definition. However, as Arundel and Kemp (2009, p.1) note: “...this is the same 'false problem' that has been discussed in reference to the Oslo Manual on measuring innovation, with some researchers objecting that the Manual defines innovation so broadly that almost all firms should be innovators. This is true, but the solution is to use available data to identify how firms eco-innovate and the different drivers for these various 'modes' of eco-innovation".

Eco-innovations may be grouped in four categories: (1) environmental technologies, (2) organizational innovation, (3) product and service innovation, and (4) green system innovations. Table 1 provides an overview of these four categories, including specific examples. ${ }^{2}$ Of these main categories, green system innovations are probably the most difficult to measure, since they are not about identifiable innovations but about evolving systems involving multiple changes. The other types of innovations can in principle be measured more directly and are more suitable for informing policymakers about changes in the nature of ecoinnovation, for example whether there is a shift from curative solutions (that treat pollution) to preventive solutions. Cleaner production processes and products are preventive solutions.

\footnotetext{
${ }^{2}$ New materials such as lightweight composite materials could be separated out as an additional category. The present typology subsumes them under product innovations.
} 
Table 1. MEI classification of eco-innovation

\section{A. Environmental technologies}

- $\quad$ Pollution control technologies including waste water treatment technologies

- Cleaning technologies that treat pollution released into the environment

- Cleaner process technologies: new manufacturing processes that are less polluting and/or more resource efficient than relevant alternatives

- Waste management equipment

- Environmental monitoring and instrumentation

- Green energy technologies

- Water supply

- Noise and vibration control

B. Organizational innovation for the environment:

- Pollution prevention schemes

- Environmental management and auditing systems: formal systems of environmental management involving measurement, reporting and responsibilities for dealing with issues of material use, energy, water and waste. Examples are EMAS and ISO 14001.

- Chain management: cooperation between companies so as to close material loops and to avoid environmental damage across the value chain (from cradle to grave)

C. Product and service innovation offering environmental benefits:

- New or environmentally improved products (goods) including eco-houses and buildings

- Green financial products (such as eco-lease or climate mortgages)

- Environmental services: solid and hazardous waste management, water and waste water management, environmental consulting, testing and engineering, other testing and analytical services

- Services that are less pollution and resource intensive (car sharing is an example)

D. Green system innovations:

- Alternative systems of production and consumption that are more environmentally benign than existing systems: biological agriculture and a renewables-based energy system are examples

Now we have set the boundaries for eco-innovation, the next question is how it can be evaluated and measured by patent statistics. To this we turn next.

\section{Measuring eco-innovations with patent data}

\subsection{Background}

In this section, we discuss to what extent patents can provide a relevant indicator of eco-innovations, and in particular what kind of environmental innovations can be evaluated through patents. Based on a summary of the empirical literature on eco-patents, we review the different types of indicators based on patent data and the attributes of innovative activities they are supposed to evaluate.

For measuring innovative activities patents are frequently used. The main advantage of patents is that they are publicly available for rather long time series and provide detailed technological information. The long time series make patents unique among innovation indicators. Using patent data, it is possible for researchers to collect data in highly 
disaggregated forms and to subject this to statistical analysis. The cost of processing patent data is also lower than the cost of survey-based data. As a measure of inventiveness, patents have a close link to technical innovation.

There are, however, also some limits and weaknesses. First, patents measure inventions rather than innovations, where the latter essentially refers to the actual application of inventions. Second, the value distribution of patents is highly skewed. That is, only a few patents are commercially valuable; the majority of patents have little or no commercial value. When used as a measure for innovation, patents with no commercial value should be discarded. The propensity to patent is known to differ between sectors and/or countries, and may change over time. For some innovations patents are not a good measure. All these things are important issues for eco-innovation measurement as we will see.

The main attractiveness of patents is that they allow researchers to collect and use data in highly disaggregated form and to subject these data to statistical or econometric analysis (to determine the influence of particular determinants). It is mainly for this reason that patents have emerged as relevant indicators to measure eco-innovations.

Eco-patents can be identified according to different methodologies - mainly based on International Patent Classification (IPC) codes and keywords- which are discussed in the next section. With the help of methodologies, a patent database can be build for specific domains of environmental technologies. However in order to be picked up as an eco-patent, the environmental gain of the considered innovation must be explicit and described in the patent. If the environmental impact is a non-intentional side effect of the innovation, this effect will not appear in the claims and in the description of the patented technology. In that case, it will not be possible to identify the patented technology as an eco-innovation, unless the researcher knows ex ante that this technology has an indirect positive impact upon environment. As a consequence, eco-patents mainly concern environmentally motivated or intentional ecoinnovations.

A second limitation is that it is primarily technical inventions which are patented. New business methods and organizational innovations are almost never patented, for the reason that it is impossible to patent them as there is no clear invention underlying it. So for this type of innovation patent analysis is not suited. Of system innovations, only inventions in technical components can be analyzed through patent analysis. Moreover, given that firms are more likely to patent research that results in new products, rather than research that results in new processes, research on environmental innovation that uses patent statistics is likely to focus primarily on product eco-innovations (Popp, 2005). Eco-patents data tend to cover mostly end-of-pipe technologies, because they are also more easily identifiable. Clean process technologies are more difficult to identify. It may be possible only if the researcher knows ex ante the clean process technology under consideration, which has been identified as an ecoinnovation, and so is able to use the relevant keywords to identify the patents linked to this technology. Since changes in production processes and product characteristics are increasingly more prevalent as a means of addressing environmental concerns than end-ofpipe strategies, this problem is likely to become more acute with time (Frondel et al., 2008).

A last limitation is that eco-patents only concern eco-innovations that are new to the world, or at least characterized by a degree of novelty which is superior to the minimum degree of novelty necessary for an innovation to be patentable. In comparison to the definition of eco-innovation given in section 2, it means that eco-patents only concern a small set of eco-innovations characterized by a high degree of novelty. 
A clear strength of patents is that they provide a set of disaggregated data on innovation and a set of bibliographic information (e.g., priority/application dates, identity and home country of inventor, technical description of the invention, claims, IPC classifications and citations) which may be used to evaluate different properties of innovative activities (for example, whether the patent has commercial value, which for innovation is a crucial aspect). Based on the general literature on patents, we can identify five attributes of environmental innovative activities that can be measured through patents: the level of eco-inventive activities, international technology diffusion, directions of research and technological competencies of organizations, sources of eco-inventions, technological spillovers and knowledge flows. We will elaborate on each of these below.

\subsection{Five attributes of environmental innovation and patents}

\section{The level of eco-inventive activities}

Given that patent applications are usually filed early in the research process (Griliches, 1990), they are not only a measure of innovative output, but also an indicator of the level of innovative activity itself (Popp, 2005). ${ }^{3}$ For example, Cohen et al. (2000) emphasize that there is a mutual causation between $R \& D$ and patents, and that patenting tends to stimulate $R \& D$. In the same way, Lanjouw and Mody (1996) find a strong positive correlation between patents and R\&D in alternative energy for the US. In other words, patent counts should be expected to increase as R\&D activity increases. However, the correlation is not systematic. Eco-patent counts (the number of patents linked to environmental technologies) are often used to evaluate the level of eco-inventive activities in specific technological fields, industries or countries. In that case, the total number of eco-patents per year or the share of eco-patents (over the total number of patent applications) is considered as a proxy of eco-innovation activities.

In most cases, eco-patent counts are used in order to investigate the link between environmental policy and technological change. For instance, to estimate the effects of environmental policy instruments and (energy) prices on eco-innovation (Popp, 2002). Based on econometric models, this type of empirical study can be carried out at countries' level by considering all the patent applications linked to environmental technologies in general (for example, Lanjouw and Mody (1996), Brunnermeier and Cohen (2003), Marinova and McAleer (2003), Sun et al., (2008)), or for a specific set of environmental technologies (for example, de Vries and Withagen (2005) and Dekker et al. (2009) for sulphur dioxide $\left(\mathrm{SO}_{2}\right)$ abatement; Popp (2003, 2006) for air pollution control technologies; Popp (2002) and Johnstone et al. (2008) for alternative energy technologies).

\footnotetext{
${ }^{3}$ It is better to talk about inventive activity instead of innovative activity, as they are different things. Innovative activity involves far more than the development and use of an invention. Innovation involves production, design and marketing.
} 
Patents may also be used to measure international technology diffusion. Patent applications at multiple countries are indicative of international diffusion of the knowledge contained in the patent (Eaton and Kortum, 1996, p. 254). Because patenting is costly, inventions are typically protected in only a small fraction of the countries of the world. This is the case even among large and technologically advanced countries: over $70 \%$ of patent families (the set of patents in different countries protecting the same invention) consist of only one patent (Putman, 1993). When an inventor wants to enlarge his protection, he has to apply for patent protection in foreign countries, which is very costly. Because the legal protection granted by a patent only applies in the country in which the patent has been granted, inventors must file patent applications in each country for which they desire protection.

In Europe inventors may choose to file an application through the European Patent Office (EPO), rather than applying to individual patent offices. The applicant designates as many of the 18 EPO member states for protection as is desired. Because EPO applications are more expensive, European inventors typically first file a patent application in their home country, and then apply to the EPO if they desire protection in multiple European countries. Because of the additional costs of filing abroad, one could argue that only the most valuable inventions are filed in several countries. ${ }^{4}$ Filing a patent application in a given country is a signal that the inventor expects the invention to be profitable in that country which is seen as a potential market (e.g., Eaton and Kortum, 1999). ${ }^{5}$ Thus, researchers can use data on multiple filings of patents (patent families) to track technology diffusion across countries. Further work is required to determine how well duplicate patents approximate international technology diffusion. For example in the case of wind-powered electric generating equipment, a positive and significant relationship between exports and duplicate patents applications is being found (Johnstone and Hascic, 2008b, p.5-6).

There are only very few studies addressing the international diffusion of environmental technologies. For instance, Lanjouw and Mody (1996) calculate the share of foreign patenting as a proxy of technology transfer and diffusion and the recent study by Dekker et al. (2009) uses patent families to study international knowledge transfers in $\mathrm{SO}_{2}$ abatement technologies.

\section{Directions of research and technological competencies of organizations}

Each patent provides a detailed description of the invention and is classified according to the International Patent Classification (IPC). ${ }^{6}$ This classification is a hierarchical system in which the whole area of technology is divided into a range of sections, classes, subclasses and groups. This system is indispensable for the retrieval of patent documents in the search for establishing the novelty of an invention or determining the state of the art in a particular area of technology. That is, these data allow for a detailed analysis of the patented invention: the description of the technology and the IPC codes can be used to distinguish between different

\footnotetext{
${ }^{4}$ The costs of patenting in additional countries are not prohibitively high, however, leading some companies to widely apply for patents.

${ }^{5}$ In the light of international environmental agreements, the study by Dekker et al. (2009) is an example that shows that inventors file for patent protection mainly in signatory countries, thus recognizing the potential markets for their inventions in these countries.

${ }^{6}$ At least one classification code is assigned to all patent documents by patent examiners.
} 
types of technological innovations and to identify the directions of research and the technological trajectories followed by organizations. The IPC codes and the description of the patented technology can be used to develop a qualitative analysis of eco-patents in order to distinguish between the different types of environmental technologies (e.g., waste disposal, recycling, water cleaning technologies) and to determine the technological field and the environmental objective of eco-innovations (e.g., air pollution control devices designed to reduce $\mathrm{NO}_{\mathrm{x}}$ emissions versus devices designed to control $\mathrm{SO}_{2}$ emissions). Moreover this information is also very useful to study the directions of research and the technological competencies developed by organizations (public organizations or private firms). The fact that a firm applies for a patent in a given technological field means that such a firm is at, or close to, the technological frontier and has advanced technological competencies in that field.

Patent portfolios of firms offer detailed information on the relevant technological areas, which is of particular relevance in order to assess the firms' spectrum of technological activities. Within this perspective, many empirical studies use patent data to analyze firms' technological diversification. For example, Frenken et al. (2004) and Oltra and Saint Jean (2008, 2009) study the evolution of car manufacturers' patent portfolios in the field of low emission vehicles. A similar analysis is that of Johnstone and Hascic (2008c) for hybrid vehicles and fuel cell technology. To summarize, eco-patents provide disaggregated data that can be used to develop micro-economic and qualitative analyses of the technological trajectories in the field of eco-innovations.

\section{Knowledge sources of eco-innovations}

From the bibliographic data on a patent, researchers can learn the identity and home country of the inventor and of the assignee (or the applicant). This information enables researchers to identify the sources of the invention and, for example, to study the relative role of public and private organizations in the innovative process. For a given technology, or a given IPC section, one can calculate the share of patents filed by private firms, universities and public laboratories. ${ }^{7}$ When focusing on private firms, patent data can also be used to study the distribution of patents across sectors and, for example, to emphasize the share of patents filed by suppliers or component manufacturers.

Another strand concentrates on joint patent applications in order to study collaborations and networks of innovators. The study by Yarime (2005), for instance, analyses university-industry collaboration in the field of photocatalyst technologies. On the basis of joint patent applications, the author maps the networks of innovators and stresses the central role of big Japanese university laboratories. In this type of work patents are used as an indicator of the relationships and technology transfers between organizations in the inventioninnovation process.

Empirical studies on the sources of inventions and on co-patenting are rather rare in the field of eco-innovations, while they are numerous in innovation studies in general. With such an approach, more can be learnt on the sources of eco-innovation, on the networks of eco-innovators and on the relative role of public and private organizations in environmental innovative activities. Again, this can contribute to a better knowledge of the process of ecoinnovation at a micro or meso level.

\footnotetext{
${ }^{7}$ For an example in the case of green chemistry, see Nameroff et al. (2004). Another example is Sun et al. (2008) who study the pattern of environmental patents by ownership in China.
} 
In recent years there have been various attempts to conceptualize the relatedness among technological fields and to find appropriate measures for knowledge spillovers. Various methodologies have been proposed on the basis of patent data: based on Scherer (1982) the 'Yale matrix' is used for measuring the spillovers flow from the innovation producing sector to the innovation-using sector; Jaffe $(1986,1989)$ measure technological relatedness among a sample of US firms by looking at the distribution of their patents across technological fields (each field corresponding to a collection of 12-digit IPC codes); Engelsman and Van Raan (1991, 1994) analyze the co-occurrence of IPC codes assigned to patents to evaluate knowledge links and spillovers; Verspagen (1997) evaluates intersectoral technology spillovers by distinguishing between the main classification IPC code and the supplementary codes. Other methodologies use patent citations, i.e. references to previous patents, since according to Jaffe et al. (1993) a reference to a previous patent indicates that the knowledge in the latter patent was in some way useful for developing the new knowledge described in the citing patent.

For a given technology, the set of patents and the citations between them can be viewed as a network of ideas and their relatedness. Using this type of interpretation, Verspagen (2005) use patent citations to describe the main paths of knowledge flows in the field of fuel cells and to map the technological trajectories underlying the development of fuel cells. Such a methodology enables to capture the cumulativeness and dynamic character of innovation.

Eco-patent citations are also used as a measure of knowledge flows across inventors and across countries. Papers using citation data include Jaffe et al. (1996, 1998), Johnson and Popp (2003) and Popp (2002, 2006). In the case of energy technologies, Popp (2002) shows that patent citations can be used as a measure of the supply of knowledge available to inventors when they engage in research. Within the same line of inquiry, Popp (2006) shows, in the case of air pollution control technologies in the United States, that earlier foreign patents do play an important role as building blocks for later domestic inventors and that the most important knowledge flows come from technologies developed first, rather than from technological proximity. These findings have important implications for the relationship between environmental policy and technological change since they suggest that transfer of environmental technologies across borders are important, which also implies a need for domestic R\&D to adapt these technologies to local markets.

Table A1 in the appendix presents a (non exhaustive) summary of the empirical literature on eco-patents and of the different indicators based on eco-patents. This survey of the literature emphasizes that eco-patents have mainly been used to evaluate the level of ecoinventive activities and the impact of policy instruments on innovation. Nevertheless, very few articles use patent data to assess other properties and dimensions of eco-innovation activities, such as diffusion, knowledge spillovers or innovation sources. The purpose of this discussion on eco-patents is to show that patent data provide a set of information that can be used to learn more on the micro-economic properties of eco-innovation activities, and in particular on the sources of eco-innovation, the directions of research and the knowledge flows. 


\section{Some practical issues on identifying eco-innovation patents}

In the previous section we gave a general account on how eco-innovative activities could be analysed through patents. The aim of the current section is to focus on the more practical issues that are involved in doing patent-related research. The main question to be addressed here is how to identify the relevant eco-patents given the various environmental domains that can be studied. By answering this question we will touch upon issues like the use of keywords in the search process, how to assess the importance of individual patents and aggregation problems. We will end by illustrating how these issues were dealt with in two studies.

As mentioned before, all patents are classified according to the IPC scheme where technological domains are (sub)divided into different categories according to a nested structure. The European Classification System (ECLA), assigned by the European Patent Office (EPO), is an extension of the IPC system in the sense that the former includes a more detailed coverage of different technological specifications. For example, the ECLA class B01D53 contains patents related to the separation of gases or vapours; recovering vapours of volatile solvents from gases; chemical or biological purification of waste gases (e.g. engine exhaust gases, smoke, fumes, flue gases and aerosols). The class B01D53 is also divided into subclasses. For example, assume that a firm who has invented a new method to control $\mathrm{SO}_{2}$ emissions, it is likely to be assigned to the class B01D53/50, referring to patents on the chemical or biological processes to reduce sulfur dioxide. The structure of such detailed classification schemes enables researchers to search specifically for relevant (abatement) technologies. This illustrates the aforementioned advantage of using patents compared to R\&D data.

The key factor in the IPC and ECLA system is that technologies are classified in a nested way. For instance, Popp (2006) employs patent statistics using patents related to pollution control technologies for nitrogen oxide $\left(\mathrm{NO}_{\mathrm{x}}\right)$ and $\mathrm{SO}_{2}$ emissions. With respect to the latter type of control technologies, Popp distinguished the classes B01D53/14H8, B01D53/50, B01D53/86B4 and F23C/10. The subclass (in bold) B01D53/14H8 is tailored to the inclusion of absorption techniques with respect to gases containing acid components and gases containing only $\mathrm{SO}_{2}$ or $\mathrm{SO}_{x}$ respectively. The subclasses B01D53/50 and B01D53/86B4 encompass technological mechanisms through which pollution control is addressed. In the same vein, the class F23C/10 contains technologies that fall under the header of mechanical engineering, but due to the sub-classification it only relates to fluidized bed combustion technologies. ${ }^{8}$

The above illustration shows that it is possible to identify the relevant patent classes, permitted the environmental technologies one is interested in are well-defined. However, it might as well be that the technologies are "scattered" across different patent classes. That is, by identifying certain patent classes it might be possible one does not account for patents that are filed in other classes. On the other hand, in essence, a class could also not be perfectly defined in the sense that it contains technologies that do not strictly pertain to the environmental technology under investigation. Thus, there might either be an under or

\footnotetext{
${ }^{8}$ See EPO’s online database esp@cenet (http:/www.espacenet.com), and go to “Classification Search” after choosing one of the country-specific portals/gateways.
} 
overstating of the amount of patents for the environmental technology one is interested in studying.

Whether this bias will be large or small is difficult to judge in advance of the patent search. However, it is relatively straightforward to minimize the overstating of patent counts by trying to solely identify those patents that relate strictly to the technology under consideration and as such to obtain a patent data set that is as "clean" as possible. One would want to reduce the "noise" as much as possible by excluding those patents that do not fit into the eco-innovation confinement we made in the previous sections. Moreover, one should be aware of the risk of double-counting of patents, since patents can be in different classes.

In sum, the above implies the existence of two possible errors when one wants to conduct (aggregate) analyses. That is, it is likely that a patent is included in a class that is not directly related to the topic under investigation and is therefore (potentially) less relevant, implying that the researcher might include irrelevant patents or patents that only indirectly relate to specific technologies and may deviate from the study's purpose. On the other hand, when selecting specific classes one might as well exclude potentially relevant patents. Or as Lanjouw and Mody (1996, p. 557) put it:

\begin{abstract}
"In choosing the IPC classes, two sources of possible error arise. If too many are selected, innovations that bear no relation to pollution abatement are included and information about environmental fields may be swamped by movements in the mistakenly included patents. If too few are selected, relevant innovations are left out. In the second case, as long as all environmentally responsive innovation in a field responds to events in a broadly similar fashion, activity in the chosen IPC classes is indicative of overall activity. Totals, of course, would be somewhat understated."
\end{abstract}

Given our definition of eco-innovations, the relevant question then is how one can effectively search and identify those patents that pertain to specific environmental responsive innovation. One effective way could be the use of technology-specific keywords as an input in the search process. For illustrative purposes let us sketch one of such procedures of assembling patent data as taken by de Vries and Withagen (2005) and Dekker et al. (2009). Both studies try to link environmental policy to innovation in $\mathrm{SO}_{2}$ abatement technologies in a cross-country setting. What follows illustrates the problem highlighted above and how they have coped with it.

Each patent has a patent number. At the EPO the granted patents are classified according to the ECLA. There are basically two routes to access EPO's database. First, one can search for patents by using the on-line search engine esp@cenet, which can be entered freely. However, because one can maximally retrieve a number of 500 patents, this on-line service is particularly useful for a first initial screening of classes and sub-classes, or for a first rough search by using keywords. Given the limit of patents one can download, De Vries and Withagen (2005) and Dekker et al. (2009) consulted the EPO directly and searched through their database with the help from experts at the office.

Their search process, using keywords, went as follows. Since they were interested in the number of patent applications related to techniques and technologies that reduce or control $\mathrm{SO}_{2}$ emissions, the search was first confined in terms of the pollutant under consideration. Given the focus on $\mathrm{SO}_{2}$, the initial step in the search routine can be done by imposing pollutant-related keywords. For example, with regard to $\mathrm{SO}_{2}$ abatement, the keywords that restrict the search within the database of the EPO were: " $\mathrm{SO}_{2}$ " and "sulfur". 
Second, keywords based upon relevant abatement techniques were applied in order to generate a set of potentially relevant patents. To do so, one first needs to make a list of technologies and techniques that are currently available (or are in development stage) to curb the emissions of $\mathrm{SO}_{2}$. For example, several techniques can be applied to reduce or remove $\mathrm{SO}_{2}$ emissions as a side product of industrial processes. Examples are conventional wet flue gas desulfurization processes or fluidized bed combustion, among others. The technologybased keywords were derived from these technological sources. For the $\mathrm{SO}_{2}$ example a keyword could be "flue" in combination with "gas" or "combust".

As a final step, the abstract of each single patent, as contained in the set generated in the second stage, was screened in order to determine whether indeed the patent was relevant. The patent was eliminated from the set if it was not related to a $\mathrm{SO}_{2}$-tailored pollution abatement technique. This step was included in order to avoid the potential error of having too many unrelated patents (see discussion above), thereby improving the quality of the patent data set. The drawback of this is that the aggregate number of patent applications may be somewhat understated. However, this type of error was preferred above the error that would occur if patents that bear no relation to pollution abatement were included. This latter type of error can be avoided by being very accurate in judging the patent on the basis of its actual content, which can be assessed through the patent abstract.

This section highlighted some practical implications when working with patent data. However, every empirical study on eco-innovation will have its own demands in terms of the required information that is needed for specific research questions. Whether it is to give an indication of overall patenting activity in or across sectors and countries, or about measuring technological spillovers or diffusion, every angle requires specific technological detail that can be retrieved from patent statistics. For those interested in conducting patent-related research, a good starting point is the book by Jaffe and Trajtenberg (2002) for a nice treatment on the various ways patent data can be employed.

\section{Conclusions}

Patents are frequently used for measuring innovative activities. For eco-innovation they are probably the most widely applied method. The main advantage of patents is that they are publicly available for rather long time periods and provide detailed technological information. The long time series make patents unique among innovation indicators. Using patent data, it is possible for researchers to collect data in highly disaggregated forms and to subject this to statistical analysis. The cost of processing patent data is also lower than the cost of surveybased data.

As a measure of invention patents have a close (if not perfect) link to technical invention. Over the last two centuries, there are very few examples of major technical inventions that were not patented. Most innovations however are not patented. This holds especially true for organisational and service innovations. The range of application of patents is growing. They cover a broad range of techniques, extending now to biotechnology and software, with first extensions towards service-related inventions (so-called "business methods"). Eco-patents mainly measure inventions that underlie green product innovations and end-of-pipe technologies, whose environmental impacts are specific aims and motivations of the inventions. For these kinds of innovations it is acceptable to use patent analysis.

The identification of eco-patents in patent databases raises methodological issues which should be taken into account when interpreting the results. In the literature two 
methodologies are used, sometimes in combination: research in specific patent classifications and/or searching for relevant keywords. The problem is that patent classification systems do not provide specific categories which cover environmental patents and there is also no widely accepted agreement in the literature as to what constitutes an environmental technology. The methodology also depends whether the analysis concerns environmental technologies in general or a specific set of technologies.

For analyzing patents researchers must have an adequate knowledge of the technologies under consideration and carefully screen patents found through a patent search. Citation analysis and patent renewal data may be used to select relevant patents for innovation and eliminate patents that have no commercial application.

The use of patent data poses also methodological difficulties. For instance, how does one allocate patent data organized by firms or by substantive patent classes into economically relevant industry or product groupings? The OECD Technology Concordance (OTC), presented in Johnstone (2002), may be used to transform IPC-based patent data into patent counts by sector of the economy, but this does not work well for patents used in multiple sectors.

The overall conclusion is that patents are a useful measure for measuring environmentally motivated innovations, such as pollution control technologies and green energy technologies, and for general purpose technologies with environmental benefits. For these types of innovations it is acceptable to use patent analysis, provided they are carefully screened. For other types of innovation, patent analysis does not appear very suitable. A good knowledge of technologies is essential to exclude non-environmental patents. 


\section{Appendix}

Table A1: Summary of the empirical literature on eco-patents and associated

\begin{tabular}{|c|c|c|c|c|}
\hline Purpose & $\begin{array}{l}\text { Type of } \\
\text { indicators } \\
\end{array}$ & Definition & Interpretation & Key references \\
\hline $\begin{array}{l}\text { Level of eco- } \\
\text { inventive } \\
\text { activities }\end{array}$ & Eco-patents count & $\begin{array}{l}\text { Cumulated number } \\
\text { of eco-patents, } 2 \text { or } 3 \\
\text { years moving average } \\
\text { of eco-patents } \\
\text { number } \\
\text { Share of eco-patents } \\
\text { in total patents, } \\
\text { national share of eco- } \\
\text { patents in the overall } \\
\text { number of patents in } \\
\text { the same } \\
\text { technological field }\end{array}$ & $\begin{array}{l}\text { Evolution through } \\
\text { time and across } \\
\text { countries of eco- } \\
\text { patenting, impact of } \\
\text { environmental } \\
\text { policy on (induced) } \\
\text { innovation, supply } \\
\text { and demand side } \\
\text { determinants of eco } \\
\text { innovations. } \\
\text { NB: Normalization } \\
\text { by total patents to } \\
\text { correct the biases } \\
\text { linked to differences } \\
\text { in propensity to } \\
\text { patent across } \\
\text { countries or across } \\
\text { technological fields. }\end{array}$ & $\begin{array}{l}\text { Brunnermeier and Cohen } \\
\text { (2003) } \\
\text { Jaffe and Palmer (1997) } \\
\text { Johnstone (2005) } \\
\text { Johnstone and Hascic (2007) } \\
\text { Johnstone et al. (2007) } \\
\text { Lanjouw and Mody (1996) } \\
\text { Nameroff et al. (2004) } \\
\text { Marinova and McAleer } \\
\text { (2003) } \\
\text { Popp (2002, 2003, 2006) } \\
\text { Taylor et al. (2003) } \\
\text { de Vries and Withagen } \\
\text { (2005) }\end{array}$ \\
\hline $\begin{array}{l}\text { International } \\
\text { technology } \\
\text { diffusion }\end{array}$ & $\begin{array}{l}\text { Eco-patents share } \\
\text { Patent family size }\end{array}$ & $\begin{array}{l}\text { Share of foreign } \\
\text { patenting } \\
\text { Average patent } \\
\text { family size }\end{array}$ & $\begin{array}{l}\text { International } \\
\text { technology transfer } \\
\text { and diffusion }\end{array}$ & $\begin{array}{l}\text { Lanjouw and Mody (1996) } \\
\text { Johnstone and Hascic (2007) } \\
\text { Dekker et al. (2009) }\end{array}$ \\
\hline $\begin{array}{l}\text { Directions of } \\
\text { research and } \\
\text { technological } \\
\text { competencies of } \\
\text { organizations }\end{array}$ & $\begin{array}{l}\text { Eco-patent count } \\
\text { in specific } \\
\text { environmental } \\
\text { technology fields }\end{array}$ & $\begin{array}{l}\text { Cumulated nb of } \\
\text { patents, patents } \\
\text { number per year }\end{array}$ & $\begin{array}{l}\text { Technological } \\
\text { trajectories of } \\
\text { organizations, } \\
\text { evolution of various } \\
\text { technological } \\
\text { options } \\
\text { Technological } \\
\text { diversification of } \\
\text { firms, technological } \\
\text { variety }\end{array}$ & $\begin{array}{l}\text { Nameroff et al. (2004) in the } \\
\text { case of green chemistry } \\
\text { Three examples in the case } \\
\text { of low emission vehicles: } \\
\text { Frenken et al. (2004), } \\
\text { Hekkert and van den Hoed } \\
\text { (2006), Oltra and Saint Jean } \\
\text { (2008, 2009) }\end{array}$ \\
\hline $\begin{array}{l}\text { Sources of eco- } \\
\text { innovations }\end{array}$ & $\begin{array}{l}\text { Eco-patent count } \\
\text { and eco-patent } \\
\text { share }\end{array}$ & $\begin{array}{l}\text { Number or share of } \\
\text { eco-patents per type } \\
\text { of inventors or } \\
\text { applicants }\end{array}$ & $\begin{array}{l}\text { Sources of eco- } \\
\text { innovations and } \\
\text { relative role of } \\
\text { public and private } \\
\text { organizations } \\
\end{array}$ & $\begin{array}{l}\text { Nameroff et al. (2004), } \\
\text { Yarime (2005), Sun et al. } \\
\text { (2008) }\end{array}$ \\
\hline $\begin{array}{l}\text { Technological } \\
\text { spillovers and } \\
\text { knowledge } \\
\text { flows }\end{array}$ & Patent citations & $\begin{array}{l}\text { Citation rate of } \\
\text { patents }\end{array}$ & $\begin{array}{l}\text { Knowledge flows in } \\
\text { a given } \\
\text { technological field, } \\
\text { spillovers among } \\
\text { organizations, } \\
\text { patent value }\end{array}$ & $\begin{array}{l}\text { Popp (2002, 2006), } \\
\text { Marinova and Mc Aleer } \\
\text { (2003), Johnson and Popp } \\
\text { (2003), Verspagen (2005) }\end{array}$ \\
\hline
\end{tabular}




\section{Bibliographie}

Arundel A. and Kemp R. (2009), "Measuring eco-innovation", UNI-MERIT Research Memorandum, 2009-017.

Brunnermeier S.B. and Cohen M.A. (2003), "Determinants of environmental innovation in US manufacturing industries", Journal of Environmental Economics and Management, Vol.45, pp.278-293.

Cohen W., Nelson R.R. and Walsh J.P. (2000) et al. (2000) "Protecting their intellectual assets: appropriability conditions and why U.S. manufacturing firms patent (or not), NBER Working Paper 7552, February 2000, http://www.nber.org/papers/w7552.

Dekker, T., Vollebergh, H., de Vries, F.P. and Withagen, C. (2009), "How international environmental agreements trigger knowledge transfers: evidence from $\mathrm{SO}_{2}$ protocols”, Working Paper.

Eaton J. and Kortum S. (1996), "Trade in ideas. Patenting and productivity in the OECD”, Journal of International Economics, Vol.40, pp.251-278.

Eaton J. and Kortum S. (1999), "International technology diffusion: theory and measurement”, International Economic Review, Vol.40, pp.537-570.

Engelsman E.C. and Van Raan A.F.J. (1991), “Mapping of Technology, A First Exploration of Knowledge Diffusion Amongst Fields of Technology", Report to the Netherlands Ministry of Economic Affairs (1991) published in the Policy Studies on Technology and Economy (BTE) Series, Nr. 15 (ISSN 0923-3164), The Hague.

Engelsman E.C. and Van Raan A.F.J. (1994), “A patent-based cartography of technology”, Research Policy, Vol. 23(1), pp.1-26.

Frenken K., Hekkert M. and Godfroij P. (2004) 'R\&D portfolios in environmentally friendly automotive propulsion: variety, competition and policy implications', Technological Forecasting and Social Change, vol.71, pp. 485-507.

Frondel M., Horbach J. and Rennings K. (2008), "End-of-pipe or cleaner production? An empirical comparison of environmental innovation decisions across OECD countries", in Johnstone N. (ed.), 2008, Environmental Policy and Corporate Behaviour, Edward Elgar, OECD, 2007.

Fussler, C. and P. James (1996) Driving Eco-innovation - A Breakthrough Discipline for Innovation and Sustainability, Financial Times/ Prentice Hall.

Griliches, Z. (1990), "Patent statistics as economic indicators: A survey”, Journal of Economic Literature 28(4): 1661-1707.

Hekkert M. and Van den Hoed R. (2006), "Competing technologies and the struggle towards a new dominant design: the emergence of the hybrid vehicle at the expense of the fuel cell vehicle", Greener Management International, Issue 47, pp.29-47.

Jaffe A.B. (1986), "Technological opportunity and spillovers of R\&D: evidence from firms' patents, profits and market value", American Economic Review, Vol.76, pp.984-1001.

Jaffe A.B. (1989), "Characterising the technological position of firms with application to quantifying technological opportunity and research spillovers", Research Policy, Vol.18, pp.87-97. 
Jaffe A.B., Trajtenberg M. and Henderson R. (1993), "Geographic localization of knowledge spillovers as evidenced by patent citations", Quarterly Journal of Economics, Vol.108(3), pp.577-598.

Jaffe A.B. and Trajtenberg M. (1996), "Flows of knowledge from universities and federal labs: modeling the flow of patent citations over time and across institutional and geographic boundaries", Proceeding of the National Academy of Sciences, Vol.93, pp.12671-677.

Jaffe A.B. and Trajtenberg M. (2002), Patents, Citations and Innovations: A Window on the Knowledge Economy, The MIT Press, Cambridge MA.

Jaffe A.B. and Palmer K. (1997), "Environmental regulation and innovation: a panel data study", Review of Economics and Statistics, Vol.79, pp.610-619.

Jaffe A.B., Fogarty M.S. and Banks B.A. (1998), "Evidence from patents and patent citations on the impact of NASA and other federal labs on commercial innovation", Journal of Industrial Economics, Vol.46(2), pp.183-205.

James, P., (1997) 'The Sustainability Circle: a new tool for product development and design', Journal of Sustainable Product Design 2: 52:57.

Johnson D.K.N. (2002), “The OECD Technology Concordance (OTC): Patents by industry of manufacture and sector of use”, OECD, DSTI, Working Paper n²002/5.

Johnson D.K.N. and Popp D. (2003), "Forced out of the closest: the impact of the American inventors protection act on the timing of patent disclosure", RAND Journal of Economics, Vol.34, pp.96-112.

Johnstone, N. (2005), "Environmental Policy, Technological Innovation and Patent Activity: Initial Empirical Results and Project Progress", OECD Report ENV/EPOC/WPNEP(2005)3

Johnstone, N. and Hascic I. (2007), "Policy vs. consumer pressure: innovation and diffusion of laternative bleaching technologies in the pulp industry", OECD Report, ENV/EPOC/WPNEP(2007)3

Johnstone, N., Hascic I. and Popp D. (2008), "Renewable Energy Policies and Technological Innovation: Evidence Based On Patent Counts”, NBER Working Paper No. 13760.

Johnstone, N., and Hascic, I. (2008a) Preliminary indicators of eco-innovation in selected Environmental Areas, ENV/EPOC/WPNEP(2008)7, OECD, Paris.

Johnstone, N., and Hascic, I. (2008b) Eco-innovation: Environmental Policy and Technology Transfer, ENV/EPOC/WPNEP(2008)6, OECD, Paris.

Johnstone, N., and Hascic, I. (2008c) Encouraging Sustainable Manufacturing and EcoInnovation, DSTI/IND(2008)8, OECD, Paris.

Kemp, R, Arundel, A. and K. Smith (2001), Survey Indicators for Environmental Innovation, paper for international conference Towards Environmental Innovation Systems, 27-29 Sept, 2001, Garmisch Partenkirchen, Germany.

Kleinknecht A., K. van Montfort, E. Brouwer (2002) 'The non-trivial choice between innovation indicators', Economics of Innovation and New Technologies, Vol. 11(2): 109 $-121$.

Lanjouw. J.O. and A. Mody (1996) "Innovation and the international diffusion of environmentally responsive technology”, Research Policy 25: 549-571. 
Lanjouw, J.O, A. Pakes and J. Putnam (1998), "How to count and value intellectual property: The uses of patent renewal and application data”, Journal of Industrial Economics 46(4): 405-432.

Marinova, D. and McAleer, M. (2003) 'Environmental Technology Strengths: International Rankings based on US patent data', http://ideas.repec.org/p/tky/fseres/2003cf204.html

Nameroff T.J., Garant R.J., Albert M.B. (2004) 'Adoption of green chemistry: an analysis based on US patents', Research Policy, Vol.33, pp. 959-974.

OECD (2004) Patents and Innovation: Trends and challenges, OECD, Paris.

OECD (2005), Oslo manual guidelines for collecting and interpreting innovation data. Organisation for Economic Co-operation and Development: Statistical Office of the European Communities, Paris.

Oltra V. and Saint Jean, M. (2008), "Sectoral systems of environmental innovation: an application to the French automotive industry", Technological. Forecasting and Social Change, 2008, doi:10.1016/j.techfore.2008.03.025.

Oltra V. and Saint Jean, M. (2009), "Variety of technological trajectories in low emission vehicles (LEVs): a patent data analysis", Journal of Cleaner Production, Vol.17, Issue 2, January 2009, pp.201-213.

Popp, D. (2002), "Induced innovation and energy prices", The American Economic Review, Vol.92 n¹, pp.160-180.

Popp, D. (2003), "Pollution Control Innovations and the Clean Air Act of 1990", Journal of Policy Analysis and Management, Vol.93, pp.390-409.

Popp D. (2005), "Lessons from patents: using patents to measure technological change in environmental models”, Ecological Economics, Vol.54, n², pp.2096226.

Popp, D. (2006), "International Innovation and Diffusion of Air Pollution Control Technologies: The Effects of $\mathrm{NO}_{\mathrm{X}}$ and $\mathrm{SO}_{2}$ Regulation in the U.S., Japan and Germany", Journal of Environmental Economics and Management, Vol.51, pp.46-71.

Putman J. (1993), "Who invests in the international patent system", Mimeo Yale University.

Schankerman, M. and A. Pakes (1986), "Estimates of the value of patent rights in European countries during the post-1950 period”, The Economic Journal 96: 1052-1076.

Scherer F.M. (1982), "Interindustry technology flows in the United States", Research Policy, Vol.11, pp.227-245.

Schmookler, J. (1966), Invention and Economic Growth, Harvard University Press, Cambridge MA.

Sun Y., Lu Y., Wang T., Ma H. and He G. (2008), "Pattern of patent-based environmental technology innovation in China, Technological Forecasting and Social Change, Vol.75, pp.1032-1042.

Taylor M., Rubin E.S. and Hounshell, D.D. (2003), "Effect of government actions on technological innovations for SO2 control", Environmental Science and Technology, Vol.37, pp.4527-4534.

Technopolis (2008), Eco-Innovation. Final Report For Sectoral Innovation Watch, Europe Innova. 
Verspagen B. (1997), "Measuring inter-sectoral technology spillovers: estimates from the European and US patent office databases", Economic System Research, Vol.9(1), pp.4967.

Verspagen, B. (2005) Mapping Technological Trajectories as Patent Citation Networks. A Study on the History of Fuel Cell Research, MERIT-Infonomics Research Memorandum Series 2005-020.

de Vries, F.P., and C. Withagen (2005), "Innovation and Environmental Stringency: The Case of Sulfur Dioxide Abatement", CentER Discussion paper 2005-18, Tilburg University.

Yarime M. (2005), "Coevolution of Environmental Regulation and Innovation Network: The Development of Lead-Free Solders in the United States, Europe, and Japan”, Paper presented at the Fourth European Meeting on Applied Evolutionary Economics (EMAEE), Utrecht, The Netherlands, May 19-21 (2005). 


\title{
Cahiers du GREThA Working papers of GREThA
}

\section{GREThA UMR CNRS 5113}

\author{
Université Montesquieu Bordeaux IV \\ Avenue Léon Duguit \\ 33608 PESSAC - FRANCE \\ Tel : + 33 (0)5.56.84.25.75 \\ Fax : + 33 (0)5.56.84.86.47
}

www.gretha.fr

\section{Cahiers du GREThA (derniers numéros)}

2008-20 : LAYAN Jean-Bernard, LUNG Yannick, Attractivité et agglomération de l'industrie automobile au Maroc et en Tunisie : une analyse comparative

2008-21: CABANNES Michel, La place de la sphère résidentielle dans le développement territorial : Quelques éléments d'appréciations

2008-22 : NICET-CHENAF Dalila, ROUGIER Eric, Recent exports matter: export discoveries, FDI and Growth, an empirical assessment for MENA countries

2008-23 : MAGDALOU Brice, MOYES Patrick, Social Welfare, Inequality and Deprivation

2008-24 : BERR Eric, Le développement soutenable dans une perspective post keynésienne: retour aux sources de l'écodéveloppement

2008-25 : BERROU Jean-Philippe, COMBARNOUS François, Ties configuration in entrepreneurs' personal network and economic performances in African urban informal economy

2008-26 : AMABLE Bruno, LUNG Yannick, The European Socio-Economic Models of a Knowledge-based society. Main findings and conclusion

2008-27 : MAROUANE Alaya, NICET-CHENAF Dalila, ROUGIER Eric, The law of growth and attraction: an endogenous model of absorptive capacities, FDI and income for MENA countries

2008-28 : OLTRA Vanessa, Environmental innovation and industrial dynamics: the contributions of evolutionary economics

2009-01 : MONTALBAN Matthieu, L'influence de la financiarisation sur les modèles productifs dans l'industrie pharmaceutique: domination et contradictions de la conception du contrôle blockbuster

2009-02 : CARAYOL Nicolas, LAHATTE Agenor, Dominance relations and universities ranking 2009-03 : PETIT Emmanuel, Emotions et décision économique dans le jeu de l'ultimatum

2009-04 : BLANCHETON Bertrand, JEGOUREL Yves, Les fonds souverains : un nouveau mode de régulation du capitalisme financier?

2009-05 : OLTRA Vanessa, KEMP René, DE VRIES Frans P., Patents as a Measure for EcoInnovation

La coordination scientifique des Cahiers du GREThA est assurée par Sylvie FERRARI et Vincent FRIGANT. La mise en page est assurée par Dominique REBOLLO. 